УДК 347.4

DOI https: / / doi.org/10.32837 / yuv.v0i1.2092

\author{
П. Гуйван, \\ кандидат юридичних наук, заслужений юрист України, \\ професор \\ Полтавського інституту бізнесу \\ Міжнародного науково-технічного університету імені академіка Юрія Бугая
}

\title{
ЦИВІЛЬНА ВІДПОВІДАЛЬНІСТЬ ЯК ЕЛЕМЕНТ ОХОРОННОГО МАТЕРІАЛЬНОГО ПРАВОВІДНОШЕННЯ
}

У сучасному світі є досить широкий спектр неправомірних діянь, спрямованих на порушення суб'єктивного цивільного права. Сутність конкретних загроз і впливів та їх спрямованість бувають різними. Позаяк специфіка кожної галузі визначає механізми ii правового забезпечення, природно, що порушення цивільних прав особи мають певні відмінні характеристики, що виокремлюють їх у національному правовому полі. Застосування конкретного виду охоронного заходу як способу реагування на посягання сприяє більшій визначеності правозастосування, зумовлює єдність юридичних механізмів та законодавчих і наукових концепцій. Основною засадою запровадження дієвої системи заходів цивільно-правової відповідальності у сфері матеріального обороту $€$ забезпечення адекватної протидіi прагненням порушити відповідні права громадян і організацій. При цьому, на відміну від інших заходів, спрямованих проти порушників, організаційного чи технічного гатунку, засоби цивільної відповідальності мають свій специфічний предмет: вони покликані створити правопорушнику матеріальні незручності шляхом позбавлення чи зменшення його майнових благ.

У нашій цивілістиці поширеною є теза, згідно з якою реалізація позовного домагання є засобом притягнення порушника матеріального суб'єктивного права до відповідальності [1, с. 85]. Однак на сучасному етапі розвитку науки подібний підхід виглядає застарілим. Навряд чи він нині відповідає сутності реальних охоронно-правових взаємин, котрі виникають у разі правопорушення. Радше слід вести мову про те, що відповідальність є одним 3 важливих елементів охоронного правовідношення. Розробка та застосування адекватних заходів протидії різним ризикам та загрозам, які тягнуть порушення суб'єктивних прав, шляхом притягнення правопорушників до цивільної відповідальності забезпечує ефективне поновлення прав та належну компенсацію потерпілим. 3 іншого боку, засади запровадження відповідальності не обов'язково грунтуються на позбавленні порушника матеріальних благ. Дієвість заходів відповідальності полягає ще і в тому, що саме їх існування має попереджувальний ефект. Це дозволяє попередити настання суспільно шкідливих наслідків у результаті неправомірних дій учасників правовідносин. Тому цивільно-правова відповідальність як система правових засобів має всеосяжно i повно використовувати наявні в піi розпорядженні правові засоби, які є одним із найважливіших способів вираження сутності цивільного права. Як указує I.C. Канзафарова, елементи цивільно-правової відповідальності як системи правових 
засобів повинні бути так взаємопов'язані, щоб забезпечити належну реалізацію передбачених чинним законодавством правомочностей та виконання закріплених у ньому юридичних обов'язків, тобто щоб система загалом забезпечувала та гарантувала захист цивільних прав та інтересів суб'єктів цивільного права і здійснювала штрафний і виховний вплив на правопорушників. Зазначене положення відображає концепт цивільноправової відповідальності як системи певних цивільно-правових засобів. Власне, цивільно-правові засоби самі по собі формують субстрат системи, а відносини між ними, які відповідають концепту, становлять структуру досліджуваної системи [2, с. 16-17].

Зазначені, безумовно, важливі та актуальні питання знайшли відтворення у працях таких цивілістів, як: О.Е. Лейст, О.С. Іоффе, О.О. Красавчиков, Є.О. Харитонов, В.В. Бутнєв, А.С. Комаров, I.C. Канзафарова та інші. У вказаних роботах увага вчених була сконцентрована на різних аспектах забезпечення дієвості засобів цивільно-правової відповідальності, з'ясовувалися питання юридичного оформлення можливості потерпілого за рахунок їхнього застосування відновити порушене право в повному обсязі. Водночас не напрацьовано єдиного правового підходу до визначення сутності правового статусу уповноваженої та зобов'язаної осіб у охоронному відношенні, не напрацьовано загальних правил стосовно існування пов'язаності санкцій з державним примусом, розмежування заходів відповідальності та інших негативних наслідків, що настають для порушника. Тож, метою цієї праці є вивчення правових інструментів, що гарантують належне виконання матеріального обов'язку особи у охоронному зобов'язанні, та адаптація вказаних підходів до національної системи права.

Щодо визначення санкцій та їх співвідношення 3 поняттям відпові- дальності ми дотримуємося висловленої в літературі думки, що санкція це міра майнових чи інших невигідних для особи наслідків у разі правопорушення [3, с. 190-191]. Нині у цивілістиці все більшого поширення набуває концепція, згідно з якою засоби захисту суб'єктивного права слід поділяти на відповідальність та інші засоби [4, с. 200]. Таким чином, відповідальність $є$ більш вузьким поняттям порівняно із засобами правового захисту. У такому контексті санкціями є будьякі негативні наслідки, що можуть настати в результаті державного примусу. Загальний невичерпний їхній перелік визначається положеннями статті 16 ЦКУ. До них також можна віднести і такі заходи, що напряму не впливають на майновий стан порушника та потерпілого, проте мають забезпечувальне значення та спрямовані на попередження порушення у майбутньому чи припинення відношення. Це, наприклад, такі оперативні заходи впливу, як переведення неналежного боржника на попередню оплату, відмова від прийняття простроченого виконання, відмова від договору тощо (хоча ми не можемо погодитися 3 невиправданим розширенням такого переліку, зокрема щодо віднесення до санкцій, скажімо, притримання чи зарахування [5, с. 129-130]). I саме можливістю застосування санкцій забезпечується належне та своєчасне здійснення суб'єктивного цивільного права та виконання кореспондуючого йому юридичного обов'язку.

3 такої точки зору цивільна відповідальність являє собою один 3 різновидів санкцій і є впливом на правопорушника шляхом позбавлення його певних майнових прав чи покладення на нього додаткових майнових обов'язків [6, с. 9]. Наприклад, коли замовник, незважаючи на своєчасне попередження 3 боку підрядника, у відповідний строк не усуне обставин, що загрожують якості або придатності результату роботи, підрядник 
має право відмовитися від договору та право на відшкодування збитків (ч. 1 ст. 848 ЦКУ). Таким чином, обов'язок відшкодувати завдані збитки $€$ відповідальністю винного суб'єкта, a iii розмір визначається величиною збитків. Засоби відповідальності проявляються в наслідках порушення наявного зобов'язання (договірна відповідальність) або в наслідках самого правопорушення, які породжують нове зобов'язання (деліктна відповідальність) [7, с. 460]. При цьому заходи захисту суб'єктивного права, в тому числі і юридична відповідальність, мають бути економічно обгрунтованими [8, с. 5].

Шляхом реалізації охоронної матеріально-правової норми здійснюються заходи юридичної відповідальності та захисту суб'єктивних прав. Тому можна погодитися, що відносини цивільно-правової відповідальності $€$ різновидом охоронних правовідносин. 3 іншого боку, останні не зводяться лише до відповідальності, а охоплюють і інші взаємини, пов'язані із захистом права. Так, залежно від змісту відношення та способу захисту порушеного права до зобов'язаної особи, котра порушила умови договору щодо повернення майна, яке перебувало в оренді, в межах охоронного правовідношення може бути пред'явлена вимога про примусове виконання обов'язку (що не є заходом відповідальності) або про сплату неустойки чи відшкодування збитків (тобто застосовано відповідальність).

Протилежної точки зору на розглядувану проблему дотримувався, наприклад, M.M. Агарков, котрий не виділяв різниці між примусовим виконанням обов'язку в натурі і відшкодуванням збитків, вважаючи обидва наслідки відповідальністю боржника: борг і відповідальність $€$ не незалежними один від одного елементами зобов'язання, а лише двома аспектами одного й того ж відношення [9, с. 44]. Інші дослідники також вважали, що відповідальністю
$€$ опосередковане державним примусом виконання обов'язку в результаті будь-якого невиконання зобов'язання [10, с. 89-90]. Фактично за такої концепції відповідальність - це примус щодо виконання охоронно-правового обов'язку, який уже виник. Вказана правова конструкція, як вказував О.С. Іоффе, має два суттєві недоліки. По-перше, вона залишає поза межами підставності виникнення відповідальності таку важливу правову характеристику, як вина особи, що порушила право. Проте безспірним $€$ правило, що без вини не настає обов'язок сплатити неустойку чи відшкодувати збитки. А по-друге, зі сфери відповідальності виключаються діï самого боржника без втручання юрисдикційних органів, що спрямовані на ліквідацію наслідків порушення [7, с. 473-474]. Тому цілком справедливо відділити заходи відповідальності від інших негативних наслідків для порушника: цивільна відповідальність - це не будь-які негативні наслідки для порушника, а лише ті, які покладають на нього нові чи додаткові цивільно-правові обов'язки чи позбавляють суб'єктивних цивільних прав.

Отже, можемо стверджувати, що поряд 3 відповідальністю наявні інші невигідні для порушника наслідки, спрямовані на захист суб'єктивного цивільного права. У цивілістиці їх прийнято називати засобами (мірами) захисту права [11, с. 83-85]. Вони застосовуються до правопорушника незалежно від його вини і відновлюють майнове становище особи або припиняють неправову дію. Відповідальність завжди пов'язана 3 додатковим обтяженням порушника, а у разі інших способів захисту права таких обтяжень немає. Отже, на відміну від адміністративних чи кримінальних правовідносин, захист порушених цивільних прав відбувається не тільки шляхом застосування заходів відповідальності.

Також не можна ототожнювати реальне виконання охоронного 
зобов'язання (п. 5 ч. 2 ст. 16 ЦКУ) шляхом застосування державного примусу з відповідальністю. Приміром, відшкодування нанесених порушенням збитків та сплата неустойки $€$ класичними видами цивільно-правової відповідальності. При цьому позивач вправі звернутися до суду 3 вимогами про застосування цих обох санкцій до відповідача. Принцип римського права nemo debet bis puniri pro uno delicto (не повинно бути подвійної відповідальності за одне правопорушення) у нашому законодавстві знайшов відображення у правилі, згідно з яким сплата неустойки та відшкодування збитків не звільняє зобов'язану особу від виконання зобов'язання в натурі. Реальне виконання спрямоване на виконання тієі діiі, що передбачена змістом зобов'язання, тоді як відповідальність спрямована на виконання додаткового обов'язку, який виник у результаті правопорушення [12, с. 445].

Якщо неустойка виконує функцію попередньо оціненого сторонами рівня збитків, які можливі у разі невиконання договору, що характерно для міжнародного торгового обігу [13, с. 143-145], то у такому разі вона має подвійне значення як еквівалент реального виконання та відповідальність одночасно. Відповідальність та інші види захисту прав відрізняються між собою також, керуючись принципом вини. Зокрема, відповідальність за загальним правилом настає лише за винні дії особи, тоді як інші цивільно-правові санкції застосовуються виходячи із принципу спричинення. Якщо ж ці заходи застосовуються за допомогою юрисдикційного органу (суду) як спосіб захисту права, вони охоплюються загальним механізмом реалізації охоронного правовідношення, в тому числі і щодо строків набуття примусової здатності (пред'явлення домагання) - позовної давності.

Навряд чи можна погодитися з думкою окремих авторів щодо того, що цивільно-правова відповідальність та інші засоби захисту слід розрізняти за підставами виникнення. За такою теорією відповідальність виникає лише за наявності повного складу правопорушення: протиправної поведінки, шкоди, причинного зв'язку між ними та вини правопорушника. За наявності таких умов відшкодування шкоди, нанесеної однією особою іншій, є цивільно-правовою відповідальністю. Якщо ж шкоду нанесено за відсутності повного складу правопорушення (в умовах крайньої необхідності - відсутня протиправність, джерелом підвищеної небезпеки - відсутня вина), обов'язок відшкодування не є відповідальністю [14, с. 52]. С.С. Алексєєв також наголошував, що тільки завершений склад правопорушення $€$ єдиною юридичною підставою цивільної відповідальності [15, с. 48]. Дещо по-іншому, але досить схоже кваліфікує порушення суб'єктивного права Є.О. Крашенинніков. На думку вченого, порушення права є лише тоді, коли воно охоплюється всіма ознаками цивільного правопорушення: винне невиконання регулятивного обов'язку, зафіксованість у гіпотезі охоронної цивільноправової норми, виникнення охоронного зобов'язання [16, с. 50-51].

На наш погляд, вказані підходи не $є$ повністю коректними. У жодному разі не можна ототожнювати поняття цивільного правопорушення та порушення права. Саме визначення цивільного правопорушення, безумовно, пов'язане із встановленням його складу як поняття, що охоплює всі його ознаки у сфері цивільного права, потребує, щоб було з'ясовано, хто здійснив протиправне діяння та на що воно було спрямоване. Не слід забувати, що йдеться про поняття правопорушення, котре повинне давати йому всебічну характеристику [15, с. 48]. Правопорушення не потребує особливого доказування, оскільки воно співпадає 3 продовженням правовідношення. Інша річ, порушення права. 
Це поняття має більш широкий зміст, воно охоплює наслідки різних явищ, у тому числі і правопорушення, становить певний результат. Свого часу О.С. Іоффе висловив думку, що об'єкт та форми протиправної поведінки вина - причинний зв'язок - не відображають специфіку складу правопорушення тією мірою, якою вимагає цього природа цивільно-правової відповідальності, зокрема, відповідальності, котра виникає в результаті невиконання зобов'язань [17, с. 89].

Порушення суб'єктивного права може бути спричинене не тільки діями, що кваліфікуються як цивільні правопорушення, але й іншими, що таких ознак не мають [18, с. 38]. Зокрема, порушення матеріального права особи може відбутися в результаті правомірних дій. Наприклад, внаслідок правомірних дій правоохоронних органів нанесено матеріальну шкоду певному суб'єкту. Неправильно вважати, що у такому разі підставою для позовних вимог буде невідшкодування заподіювачем добровільно завданої шкоди, оскільки такі діï не охоплюються ознаками цивільного правопорушення. Очевидно, що підставою для вимог має бути сам факт порушення майнового права. На те, що в цивільному праві відповідальність не завжди застосовується лише за наявності повного складу цивільного правопорушення, вказував Г.К. Матвєєв. Так, може існувати «безвинна» відповідальність (наприклад, за шкоду, завдану джерелом підвищеної небезпеки), відповідальність «без шкоди» (неустойка у разі відсутності збитків), відповідальність за правомірні дії (необхідна оборона, винесення акта органом держави, що порушує право власності) тощо [19, с. 7].

Українське цивільне законодавство може встановлювати правила, коли порушене правомірними діями право підлягає захисту. Порушення права може також відбутися в результаті певної події (випадок). Як пра- вило, право на захист у такому разі не виникає (немає особи порушника). Проте, якщо за законом чи договором відшкодування шкоди покладається на іншу особу, яка не $є$ порушником права, невиконання нею такого регулятивного обов'язку є порушенням. I саме усунення цього порушення може вимагати уповноважена на захист особа (страхування, рятування чужого майна тощо).

3 проведеного дослідження можемо дійти певних висновків. Як уже неодноразово зазначалося, у разі порушення суб'єктивного матеріального права виникає інше відношення, яке носить охоронно-правовий характер. Воно включає матеріальну вимогу правоволодільця до порушника і відповідний обов'язок останнього. Водночас несправедливим буде підхід, за яким виконання охоронного зобов'язання має відбуватися тільки у примусовому (через суд) здійсненні охоронного повноваження особи. При цьому невиправдано охоронно-правова матеріальна вимога зводиться лише до позовного домагання уповноваженого. Проте останній не зобов'язаний здійснювати захист свого права лише у судовому порядку. Інші несудові способи захисту також відбуваються через реалізацію охоронної вимоги особи, яка виникає з правопорушення і $€$ повноваженням охоронного правовідношення. На вказану вимогу не поширюється дія інституту позовної давності, вона, як правило, задавнюванню не підлягає та існує протягом строку існування самого охоронного права. Що ж до змісту охоронної несудової вимоги, то вона може бути такою ж, як i позовне домагання. Різновиди позовних вимог зазначені у статті 16 ЦК України як способи захисту суб'єктивного права судом. Справді, судовий орган, вирішуючи спір, застосовує саме такий спосіб захисту, який вибрав та виклав у позовному домаганні позивач. Отже, несудова охоронна вимога, гадаємо, також може полягати, наприклад, 
у припиненні дії, що порушує право, відновленні становища, яке існувало до порушення, відшкодуванні шкоди тощо. Цілком зрозуміло, що, оскільки захист порушеного матеріального права відбувається без допомоги юрисдикційного органу, то така вимога позбавлена примусової сили. Та, незалежно від того, чи пред'явлена несудова охоронна вимога, від моменту порушення права у правоволодільця виникає матеріальне право на позов. Протягом позовної давності такий суб’єкт може його реалізувати. При цьому державний примус буде засобом захисту порушеного регулятивного права і одночасно способом реалізації охоронної вимоги. Отже, як позовна, так і непозовна вимоги $€$ рівноправними механізмами захисту одного й того ж охоронюваного об'єкта - регулятивного матеріального права.

Стаття присвячена дослідженню актуального наукового питання про сутність циивільноправової відповідальності як механізму адекватного реагування правоволодільия та суспільства на порушення. У праці розглядається такий вид юридичного відношення в контексті його взаємозв'язку з таким правовим явищем, як охоронне правовідношення. Обстоюється визначальна теза, що иивільна відповідальність є важливим, але не єдиним елементом охоронного відношення. Адже застосування заходів протидії різним ризикам та загрозам, які тягнуть порушення суб'єктивних прав, шляхом притягнення правопорушників до циивільної відповідальності забезпечує ефективне поновлення прав та належн компенсацію потерпілим. Водночас засади запровадження негативних для порушника наслідків не обов'язково грунтуються на позбавленні порушника матеріальних благ. Вони базуються на комплексному застосуванні заходів, у тому числі $і$ таких, щзо мають оперативний та превентивний ефект $i$, строго кажучи, не є відповідальністю. У роботі концептуально обтрунтоване широке поняття санкиій ma їх співвідношення 3 відповідальністю як загального з частковим. Підтримана позиція, що цивільна відповідальність являе собою один з різновидів санкцій $i \epsilon$ впливом на правопорушника шляхом позбавлення його певних майнових прав чи покладення на нього додаткових майнових обов'язків. У статті також детально проаналізовано теоретичне положення про обов'язковість застосування примусу у разі притягнення порушника до відповідальності, піддано вказану тезу критиці. Доведено, що державний примус через судове рішення є дієвим, але не обов'язковим елементом охоронного відношення, що виникає мін потерпілим $i$ порушником. Наочно показано можливість реалізаціі захисної вимоги иляхом добровільного виконання ї̈ боржником $і$ таким чином задоволення охоронних вимог. У роботі також проведене розмежування понять цивільного правопорушення та порушення права. Адже порушення суб'єктивного права може бути спричинене не тільки діями, що кваліфікуються як ицвільні правопорушення, але й іншими, що таких ознак не мають. У изому відношенні порушення права є більш широким терміном, який охоплюе наслідки різних явищ, у тому числі $i$ правопорушення, становить певний результат.

Ключові слова: цивільна відповідальність, позовна давність, правопорушення.

Guyvan P. Civil liability as an element of protective material legal relationship

The article is devoted to the research of a topical scientific question about the essence of civil liability as a 
mechanism of adequate response of the right holder and society to violations. The paper considers this type of legal relationship in the context of its relationship with such a legal phenomenon as a protective legal relationship. The defining thesis is that civil liability is an important, but not the only element of the protective relationship. After all, the application of measures to counteract various risks and threats that entail violations of subjective rights, by bringing offenders to civil responsibility, ensures the effective restoration of rights and adequate compensation to victims. At the same time, the principles of introducing negative consequences for the violator are not necessarily based on deprivation of the violator of material goods. They are based on the integrated application of measures, including those that have an operational and preventive effect and, strictly speaking, are not responsible. The paper conceptually substantiates the broad concept of sanctions and their relationship with liability as general and partial. The position is supported that civil liability is one of the types of sanctions and is an influence on the offender by depriving him of certain property rights or imposing additional property obligations on him. The article also analyzes in detail the theoretical position on the mandatory use of coercion in bringing the offender to justice, and criticizes this thesis. State coercion through a court decision has been shown to be an effective but not mandatory element of the protective relationship that arises between the victim and the offender. The possibility of realization of the protective requirement by voluntary fulfilment by the debtor, and thus, satisfaction of protection requirements is clearly shown. The paper also distinguishes between the concepts of civil offense and violation of law. After all, a violation of a subjective right can be caused not only by actions that qualify as civil offenses, but also by others that do not have such signs. In this regard the violation of the law is a broader term that covers the consequences of various phenomena, including offenses, is a definite result.

Key words: civil liability, statute of limitations, offenses.

\section{Лiтература}

1. Лейст О.Э. Санкции в советском праве. Москва : Госюриздат, 1962. 238 с.

2. Канзафарова I.C. Теоретичні основи цивільно-правової відповідальності в Україні : автореф. ... Әис. докт. юрид. наук: 12.00.03. Київ, 2007. 36 c.

3. Цивільне право України. Курс лекuiü. у 6-ти томах. T. V. Kн. 1. I за ред. Р. Б. Шишки. Харків : Еспада, 2005. 224 c.

4. Харитонов E.O., Саниахметова H.A. Гражданское право. Киев : АСК, 2001. $829 \mathrm{c}$.

5. Гуйван П.Д. Темпоральний аспект існування та припинення зустрічних суб'єктивних прав. Європейські перспективи: наук.-практич. журнал. 2013. № 7. C. 129-138.

6. Красавчиков О.А. Ответственность, меры защиты и санкции в советском гражданском праве. Проблемы гражданско-правовой ответственности и защиты гражданских прав. Свердловск, 1973. Buın. 27. C. 5-16.

7. Ноффе О.С. Гражданское право. Избранные труды. Москва : Cmamym, 2000. $777 \mathrm{c}$.

8. Бутнев В.В. Юридическая ответственность и правовое государство. Юридическая ответственность: общие проблемы и отраслевые особенности. Дальневосточный гос. университет. Владивосток : ДВГУ, 1990. С. 4-5.

9. Агарков М.М. Обязательства по советскому гражданскому праву. Ученые труды ВИЮН. Москва : Изд-во НКЮ CCCP, 1940. Buın. 3. 192 c.

10. Братусь С.Н. Юридическая ответственность и законность: очерк теории. Москва : Юридическая литература, 1976. 214 C.

11. Цивільне право України: Академічний курс : підручник. У 2-х томах / За заг. ред. Я.М. Шевченко. Т. 1. Київ: Видавничий Дім «Ін Юре», 2003. 520 с. 


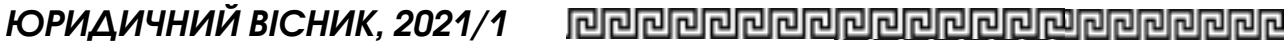

12. Харитонов Є.O., Стариев О.В. Цивільне право України : підручник. Bun. 2, переоб. і допов. Київ : Істина, 2007. $816 \mathrm{C}$.

13. Комаров А.С. Ответственность в коммерческом обороте. Москва : Юридическая литература, 1991. 208 c.

14. Носов В.A. Механизм защиты права в обязательственных правоотношениях. Механизм защиты субъективных гражданских прав. Сборник научных трудов. / Под ред. В.В. Бутнева, Ярославль. 1990. ЯрГУ. С. 47-52.

15. Алексеев С.С. О составе гражданского правонарушения. Правоведение. 1958. № 1. C. 47-53.
16. Крашенинников Е.А., Шевченко А.С. Понятие гражданского правонарушения. Юридическая ответственность: общие проблемы и отраслевые особенности. Владивосток, 1990. С. 48-52.

17. Ноффе О.С. Ответственность по советскому гражданскому праву. Ленинград : Изд ЛГУ. 1955. 310 c.

18. Горяйнов А.М. Примус $і$ изивільно-правова відповідальність. Вісник Верховного Суду України. 2012. № 3 (139). C. 36-39.

19. Матвеев Г.К. Основания гражданско-правовой ответственности. Москва : Юрид. лит., 1970. 312 с. 